\title{
PENGARUH BEHAVIOR MODELING TRAINING TERHADAP CARING GURU SEKOLAH DASAR
}

\author{
Akhtim Wahyuni \\ FKIP Universitas Muhammadiyah Sidoarjo \\ email: akhtimwahyuni@yahoo.com
}

\begin{abstract}
ABSTRAK
Caring merupakan hal yang sangat mendasar dalam mensukseskan pendidikan. Guru yang percaya pada kemampuan siswanya, maka dia akan menunjukkan bahwa dia care, dengan menempatkan siswa sebagai pusat dalam proses pembelajaran dan guru mendorong siswa untuk aktif dalam pembelajaran. Untuk mengatasi problem caring guru SD, behavior modeling training merupakan pendekatan yang efektif dalam meningkatkan caring guru, karena model ini memiliki tuntunan yang jelas dalam merubah perilaku. Apakah ada pengaruh behavior modeling training terhadap caring guru SD menjadi konsentrasi yang perlu dijawab dalam penelitian ini. Tujuan penelitian ini untuk mengetahui perbedaan caring guru yang diberi pelatihan BMT dan guru yang tidak diberi pelatihan BMT. Penelitian ini termasuk penelitian true experiment dengan desain pretest-postest design with control group. Subjek penelitian ini guru SD kelas awal (1-3) pada KKG gugus 06 di Sidoarjo berjumlah 54 orang yang terbagi dalam 2 kelas. Pemilihan sampel dilakukan secara acak. Data yang dikumpulkan diolah secara statistik dengan menggunakan teknik analisis ANOVA. Berdasarkan analisis data, ditemukan hasil penelitian: (1) penerapan BMT bagi guru SD berpengaruh terhadap caring guru, (2) efektifitas penerapan BMT dapat dilihat dari hasil uji statistik ANOVA pada kelompok kontrol dan eksperimen. Secara serempak diketahui ada perbedaan signifikan caring guru yang dilatih dan yang tidak dilatih dengan BMT.
\end{abstract}

Kata Kunci: behavior modeling training, caring, guru SD.

\begin{abstract}
'Caring' is a fundamental aspect to achieve successful education. A teacher who believes on students' potentials applies a student-centered learning process and stimulates them to be more active in learning process to show his/her "care". To overcome the problem of 'caring' for the elementary school teachers, Behavior Modeling Training is an effective approach to improve the 'caring' of the teachers because this model has clear guidance in changing the behavior. Whether there is any influence from Behavior Modeling Training to the 'caring' between the primary school teacher with and without the BMT approach is becoming the concentration of the problems to be answered in this study. This research is using the true experiment study with a pretest-posttest design in a control group. Subject of the research is two classes of 54 teachers in the fundamental grade (1-3) in the KKG 06 group in Sidoarjo. The sample is randomly selected while the collected data is statistically processed by using ANOVA analysis technique with the SPSS 20.0 program for windows. Based on the data analysis, the research found: (1) the application of BMT for primary teachers affect the 'caring' of the teachers, (2) the effectiveness of the application of BMT can be seen from the result of ANOVA statistical tests of control and experimental groups. The research simultaneously found the significant differences of the 'caring' between the teachers who were trained and not trained with BMT.
\end{abstract}

Key Words: behavior modeling training, caring, elementary teachers. 


\section{PENDAHULUAN}

Guru merupakan faktor yang dominan dan penting dalam pendidikan formal. Bahkan bagi peserta didik, guru sering dijadikan teladan. Mutu pendidikan yang baik sangat dipengaruhi kinerja guru dalam melaksanakan tugasnya sehingga kinerja guru menjadi tuntutan penting untuk mencapai keberhasilan pendidikan. Sebagai konsekuensinya, guru dituntut untuk mampu menguasai materi pelajaran, menguasai caracara menyesuaikan diri dan berkepribadian dalam menjalankan tugasnya untuk menjadi pribadi yang berkembang dan dinamis (Goodlad, 1984: 64).

Guru SD dituntut untuk mampu menyelenggarakan pembelajaran yang mendidik, berkomunikasi secara efektif, empatik, dan santun dengan peserta didik, serta mampu menampilkan diri sebagai pribadi yang jujur, berakhlak mulia, dan teladan bagi peserta didik dan masyarakat. Guru SD yang diinginkan oleh siswa adalah guru yang bisa menjalin hubungan baik dengan muridnya, sehingga akan mengerti bagaimana menghadapi muridmuridnya. Guru tersebut mengetahui metode apa yang tepat untuk mengajar (Palmer, 1998: 89).

Beberapa survey awal yang dilakukan peneliti ke beberapa SD serta wawancara dengan beberapa wali siswa, ditemukan fakta bahwa banyak guru tidak menyadari makna penting kompetensi sebagai guru SD, sehingga dalam proses belajar mengajar mereka tidak menunjukkan sikap yang mampu mendorong pembelajaran yang mendidik. Beberapa SD membuat slogan sekolah dengan $3 \mathrm{~S}$ (senyum, salam, sapa), tapi slogan tersebut hanya menjadi simbol atau slogan tanpa makna, karena hanya terpampang di tembok sekolah yang tidak dipahami dan diterapkan sehingga menjadi budaya sekolah.
Salah satu contoh dari aktivitas tersebut, pada pagi hari sebelum pembelajaran dimulai, SD yang diobservasi membiasakan salam dengan kegiatan guru bersalaman saat akan masuk kelas. Guru berbaris menyambut kehadiran siswa di gerbang sekolah yang berjejer antri berjabat tangan dengan guru sudah menjadi sebuah rutinitas. Akan tetapi pada saat menyambut dengan bersalaman, tidak jarang ditemukan guru menerima salam tangan siswa sambil ngobrol dengan guru di sebelahnya. Ada juga yang sambil menggenggam handphone dan sesekali mengangkat telpon masuk atau membalas Short Message Service (SMS). Ini menunjukkan, bahwa guru tidak memiliki pengetahuan dan pemahaman, bagaimana seharusnya melayani siswa dengan baik.

Dalam proses pembelajaran di beberapa sekolah juga ditemukan, siswa dituntut untuk berani bertanya maupun menjawab pertanyaan guru, namun apresiasi yang diterima tidak sesuai harapan siswa. Pada saat siswa menjawab pertanyaan kurang tepat, guru langsung mengalihkan ke siswa lain sambil berkata 'salah' tanpa ada penjelasan di sisi mana kesalahan siswa, bahkan ada yang lebih dari itu, bentakan juga menyertai sehingga di pembelajaranpembelajaran berikutnya, siswa takut untuk bertanya ataupun menjawab pertanyaan guru karena malu dan takut jika dikatakan 'salah' lagi. Bahkan saat mengajar di kelas, guru duduk di depan sampai pelajaran berakhir. Mereka tidak mendekati siswa sama sekali ke tempat duduknya atau saat mereka mengerjakan tugas. Fakta lain juga menjelaskan, di luar kelas, jarak antara guru dan siswa cukup jauh, karena guru memahami bahwa tugasnya sebagai guru hanya pada saat di kelas. Guru merasa tidak perlu tahu apa yang dikeluhkan, diinginkan, dan dirasakan siswa. Lebih-lebih dengan masalah siswa di rumah. 
Akhir dekade ini ada sebuah dorongan untuk menggeser pendekatan-pendekatan konvensional dengan mengimplementasikan pendekatan-pendekatan yang berfokus pada pengembangan komunitas caring (Power, Higgins, \& Kohlberg, 1989: 123). Kebanyaka siswa memanggil guru favoritnya dengan menyebut namanya. Tetapi jika ditanya apa yang diingat dari guru tersebut, seringkali dijawab bahwa guru tersebut care pada setiap siswa. Ditemukan adanya hubungan antara guru dan siswa tentang kebutuhan dasar manusia untuk mengetahui bahwa orang lain sesungguhnya care terhadapnya. Para siswa mengetahui kapan saatnya mereka diakui, dipahami, dan dihargai kemampuan unik mereka dan keingintahuan mereka oleh guru (Lumpkin, 2007: 46).

Pendekatan yang berfokus pada caring ini bermula pada penelitian persepsi siswa tentang 'guru yang baik'. Beberapa tahun kemudian hasil penelitian menunjukkan bahwa persepsi siswa tentang 'guru yang baik' adalah guru yang memiliki sikap prososial, perilaku yang bertanggung jawab, taat pada norma dan aturan kelas, serta mendorong pada aktivitas-aktivitas akademik (Wentzel, 1997: 33).

Caring secara luas diyakini menjadi aspek penting dalam pembelajaran. Kohl (1984: 58), sebagai contoh, menegaskan bahwa seorang guru memiliki kewajiban untuk care pada setiap siswa. Sedangkan Rogers dan Webb menyatakan bahwa guru yang baik adalah guru yang care, dan pembelajaran yang baik adalah pembelajaran yang tidak dapat dipisahkan dari tindakan caring (Rogers \& Webb, 1991: 26). Noddings menulis, caring seharusnya ada dalam praktek pembelajaran (Noddings, 1986: 112).

Pada saat caring diterapkan dalam pembelajaran, bentuk aktivitas yang dilakukan adalah mengutamakan dialog, menunjukkan sensitivitas pada kebutuhan dan keinginan siswa, dan memberikan materi dan aktivitas yang kaya dan penuh makna (Rogers \& Webb, 1991: 38). Caring dapat menjadi dasar bagi guru untuk membuat keputusan (Noddings, 1992: 97). Smith menyatakan bahwa caring sebagai science dalam pendidikan dan ide dalam pengajaran yang merupakan sebuah tindakan 'cinta' (dalam Murray Orr, 2002: 21). Menurut Noddings (2001: 52) caring dapat terjadi dalam hubungan dua orang, dan ini adalah sebuah aspek dari komunikasi. Komunikasi berakar pada bahasa, baik verbal maupun nonverbal. Jika terjadi komunikasi antara dua orang dengan dua bahasa yang berbeda, maka mereka akan memiliki dua cara memaknainya dengan cara yang berbeda. Miskomunikasi akan terjadi antara guru dan siswa, bergantung pada pola komunikasi yang terjadi antara keduanya.

Ada tiga dimensi caring yaitu: (1) knowing; yang melibatkan kesadaran bahwa orang lain itu memiliki kebutuhan yang unik. Hal ini berimplikasi pada pemahaman akan kebutuhan, kekuatan, kelemahan, dan keterbatasan orang lain, (2) courage; mewujudkan kepedulian pada saat seseorang butuh berkembang akan tetapi hal itu tidak diketahui. Ia berani mengatakan apa yang diinginkan dan berani menanggung resiko apapun untuk dihadapi, (3) patience; merupakan hal yang mendasar dalam caring karena dengan patience seseorang mau memberikan waktu dan tempat untuk mengekspresikan dan mengeksplorasikan dirinya. Ia juga meyakini bahwa belajar butuh waktu, serta menyayangi dan mendukung orang lain untuk maju (NKongho, 1994: 167).

Pengembangan caring yang ditulis oleh NKongho memiliki banyak implikasi pada dunia kesehatan dan profesi lainnya termasuk pendidikan. Menurutnya, sikap 
care itu mulitidimensional, melibatkan domain kognitif dan afektif (NKongho 1994: 168). Selanjutnya ia mengatakan bahwa seseorang yang memiliki tingkat caring yang tinggi, maka ia bisa menjadi model bagi orang yang memiliki tingkat caring yang rendah. Ia juga menulis, bahwa kemampuan untuk care itu sangat penting diterapkan pada semua aspek situasi dan profesi daripada aspek yang lain. Caring ability inventory yang dikembangkan oleh NKongho memiliki implikasi yang berarti dalam dunia pendidikan. Ia mengatakan bahwa dimensi caring bisa diajarkan dan bisa digunakan untuk mengukur keberhasilan perilaku, karena caring termasuk perilaku (NKongho 1994: 168).

Adapun strategi yang dapat dilakukan dalam menumbuhkan caring ada empat meliputi: (1) modeling yaitu guru menunjukkan pada siswa apa makna care pada orang lain sehingga siswa paham tidak hanya maknanya tapi juga bagaimana menjadikan diri mereka care untuk orang lain, (2) dialog yaitu melalui dialog guru dan siswa dekat satu sama lain, juga membangun kedekatan pengetahuan dengan siswa, (3) praktik yaitu guru memberikan kesempatan pada siswa untuk melakukan care pada orang lain. Tanpa mempraktekkan caring maka siswa tidak akan pernah belajar bagaimana menjadi individu yang care, (4) konfirmasi yaitu guru melihat kebaikan dari tiap individu siswa dan menemukan cara bagaimana menjaga kebaikan tersebut (Noddings, 1992: 64).

Guru sebagai pendidik mengandung arti yang sangat luas, tidak sebatas memberikan bahan-bahan pengajaran tetapi menjangkau etika dan estetika perilaku dalam menghadapi tantangan kehidupan di masyarakat. Sebagai pengajar, guru hendaknya memiliki perencanaan (planing) pengajaran yang cukup matang. Perencanaan pengajaran tersebut erat kaitannya dengan berbagai unsur seperti tujuan pengajaran, bahan pengajaran, kegiatan belajar, metode mengajar, dan evaluasi. Unsur-unsur tersebut merupakan bagian integral dari keseluruhan tanggung jawab guru dalam proses pembelajaran (Palmer, 1998: 35).

Secara umum terdapat beberapa langkah strategi yang dapat diimplementasikan dalam lingkungan kependidikan dengan tujuan bahwa peningkatan mutu pendidik dapat dilakukan melalui strategi-strategi berikut: (1) self assessment,(2) Perumusan Visi, Misi, dan tujuan, (3) Perencanaan, (4) Pelaksanaan, (5) evaluasi, dan (6) pelaporan (Atmowidoro, 2000: 47).

Behavior Modeling Training berakar pada Social Learning Theory yang dikembangkan oleh Bandura (1977: 134). Dalam penelitiannya dihasilkan, manusia belajar perilaku baru dengan cara meniru perilaku orang lain dan melalui penguatan sosial dari perilaku yang ditiru. SLT kemudian dikembangkan menjadi training process pada tahun 1970 (Sorcher and Goldstein, 1972;91) untuk keterampilan individu dalam menangani permasalahan interpersonal. Secara konsep psikologi aspek-aspek BM mengacu pada prinsip imitation, practice, and reinforcement.

Behavior Modeling Training (BMT) telah terbukti dan layak dipasarkan karena efektif dalam merubah perilaku kerja. Pada tahun 1975, pada konferensi tahunan American Psycological association, dilaporkan bahwa BM sebagai training methodology yang mampu merubah perilaku pimpinan di tempat kerja (Robinson, 1982:73). BMT menunjukkan sebagai metode pelatihan yang paling efektif untuk keterampilan mengajar, karena metode ini membolehkan pebelajar untuk meniru perilaku orang lain yang memiliki keterampilan dan ada pengawasan pada saat ia memperaktekkannya (Paul, et.al., 1983:41). 
Penelitian yang dilakukan oleh Miller \& Anderson (2009: 28), Modeling and measuring caring behaviors among nursing education faculty menunjukkan bahwa modeling merupakan cara yang efektif untuk mengajarkan caring. Dalam penelitian ini dijelaskan bahwa instruktur perawat sering menunjukkan bagaimana cara mendemonstrasikan perilaku caring dengan cara mempraktekkan perilaku caring melalui diri mereka sendiri. Modeling menjadi salah satu cara yang terbanyak digunakan dalam pendidikan perilaku yang berfokus pada pengajaran caring.

\section{METODE PENELITIAN}

Sesuai dengan tujuan penelitian, maka penelitian ini menggunakan rancangan true experiment. Desain penelitian yang digunakan dalam penelitian ini adalah pretest postest design with control group. Ciri utama rancangan ini adalah: (1) penempatan kelompok eksperimen dan kelompok kontrol secara random, (2) kelompok eksperimen diberikan perlakuan (pelatihan caring dengan behavior modeling training), sedangkan kelompok kontrol tidak diberikan perlakuan, (3) sebelum dan sesudah diberi perlakuan, kelompok diberi pretest dan posttest.

Secara garis besar tentang desain eksperimen yang digunakan dalam penelitian ini dapat dilihat pada gambar berikut:

\begin{tabular}{|cccc|}
\hline $\mathrm{R}$ & $\mathrm{O} 1$ & $\mathrm{X}$ & $\mathrm{O} 2$ \\
\hline $\mathrm{R}$ & $\mathrm{O} 3$ & - & $\mathrm{O} 4$ \\
\hline
\end{tabular}

\section{Gambar: Rancangan eksperimen dengan pretest-posttest design with control group}

Populasi penelitian ini sejumlah 67 guru kelas awal (1-3) SD di KKG gugus 06 di Sidoarjo. Dari jumlah populasi 67 guru ditentukan jumlah sampel 54 guru. Penentuan subjek penelitian dilakukan random dengan cara undian sampai terpenuhi 54 subjek penelitian yang terdiri dari laki-laki dan perempuan. Selanjutnya 54 guru kelas awal hasil penentuan random tersebut dikelompokkan menjadi dua kelompok menggunakan teknik random, hasilnya diperoleh kelompok A dan B yang masingmasing beranggotakan 27 guru. Kelompok A sebagai kelompok eksperimen dan kelompok B sebagai kelompok kontrol.

Pengumpulan data penelitian dilakukan melalui langkah-langkah sebagai berikut: (1) memberikan tes caring awal kepada subjek penelitian dengan menggunakan instrumen caring yang telah dikembangkan, (2) melaksanakan pelatihan dengan model behavior modeling training kepada kelompok eksperimen, dan (3) memberikan tes akhir kepada subjek penelitian.

Analisis data terbagi menjadi tiga, yaitu: (1) uji persyaratan analisis : a) uji normalitas data, b) uji homogenitas varian menggunakan uji error variance (Levene test). Uji normalitas data menggunakan teknik Kolmogorov-Smirnov. (2) analisis data untuk pengujian hipotesis penelitian, variabel dependen terdiri atas knowing, courage, dan patience, sehingga menganalisis pengaruh penelitian ini dimaksudkan untuk mendeskripsikan pengaruh BMT terhadap caring guru menggunakan metode statistik ANOVA. Pemeriksaan asumsi meliputi tiga hal yaitu: a) uji normalitas data untuk masing-masing kelompok menggunakan uji KolmogrovSmirnov, b) uji homogenitas varian antar kelompok menggunakan Levene's Test. 
Ketiga pemeriksaan asumsi ini menggunakan program SPSS 20.0 for wnidows. dan (3) analisis kualitatif untuk mencermati hasil penelitian, Untuk mencermati data yang diperoleh dari perhitungan statistik, maka dilakukan analisis kualitatif. Data kualitatif bersumber dari pengumpulan data sekunder, yakni data dari wawancara dan dari pengamatan selama penelitian. Analisis kualitatif dilakukan dengan cara mendeskripsikan penerapan model pelatihan dan refleksi pelatihan.

\section{HASIL DAN PEMBAHASAN}

Sebelum memberikan perlakuan pada kelompok eksperimen, maka dilakukan pretest caring guru baik untuk kelompok kontrol maupun eksperimen. Data pretest caring guru terbagi dalam kelompok kontrol (tanpa behavior modeling training) maupun perlakuan (dengan behavior modeling training). Langkah selanjutnya dilakukan uji statistik ANOVA dengan tujuan untuk mengetahui kesetaraan caring guru di kedua kelompok. Dari hasil tes menunjukkan nilai rata-rata dan standard deviasi skor pretest knowing pada kelompok kontrol adalah 37,00 dengan standard deviasi 1,44 , sedangkan pada kelompok perlakuan mempunyai rata-rata 36,67 dan standard deviasi 1,52. Pada courage, di kelompok kontrol mempunyai rata-rata 17,93 dengan standard deviasi 0,92, sedangkan pada kelompok perlakuan mempunyai rata-rata 17,89 dan standard deviasi 0,89. Deskripsi nilai patience di kelompok kontrol mempunyai rata-rata 10,26 dengan standard deviasi 0,71 , sedangkan pada kelompok perlakuan mempunyai rata-rata 10,22 dan standard deviasi 0,75. Berdasarkan nilai rata-rata pada kedua kelompok tampak rata-rata skor pretest tersebut cukup berimbang dan nilai standard deviasi yang hampir sama. Pada data pretest, perbedaan

Tabel 1. Skor Pre-Test Caring Guru

\begin{tabular}{lllll}
\hline Indikator & Kelompok & $\mathrm{N}$ & Rata-rata & Std. Deviasi \\
\hline Knowing & Kontrol & 27 & 37.00 & 1.44 \\
& Perlakuan & 27 & 36.67 & 1.52 \\
& Total & 54 & 36.83 & 1.48 \\
\hline Courage & Kontrol & 27 & 17.93 & 0.92 \\
& Perlakuan & 27 & 17.89 & 0.89 \\
& Total & 54 & 17.91 & 0.90 \\
\hline Patience & Kontrol & 27 & 10.26 & 0.71 \\
& Perlakuan & 27 & 10.22 & 0.75 \\
& Total & 54 & 10.24 & 0.73 \\
\hline
\end{tabular}

keragaman data yang terbentuk tidak dapat dikatakan bersumber dari perlakuan BMT karena guru belum diberikan intervensi apapun, sebagaimana tergambar pada tabel berikut.

Berdasarkan hasil pengukuran awal yang menunjukkan skor rendah pada ketiga variabel dan sesuai kajian pentingnya peningkatan caring guru SD, maka ditetapkan pelatihan dengan menerapkan behavior modeling training yang sesuai dengan karakteristik guru.

Setelah diberi perlakuan melalui behavior modeling training, diperoleh gambaran hasil post test sebagai berikut.

Nilai rata-rata dan standard deviasi skor posttest knowing pada kelompok 
Tabel 2 Skor Post-Test Caring Guru

\begin{tabular}{lllll}
\hline Indikator & Kelompok & $\mathrm{N}$ & Rata-rata & Std. Deviasi \\
\hline Knowing & Kontrol & 27 & 37.00 & 1.44 \\
& Perlakuan & 27 & 36.67 & 1.52 \\
& Total & 54 & 36.83 & 1.48 \\
\hline Courage & Kontrol & 27 & 17.93 & 0.92 \\
& Perlakuan & 27 & 17.89 & 0.89 \\
& Total & 54 & 17.91 & 0.90 \\
\hline Patience & Kontrol & 27 & 10.26 & 0.71 \\
& Perlakuan & 27 & 10.22 & 0.75 \\
& Total & 54 & 10.24 & 0.73 \\
\hline
\end{tabular}

kontrol adalah 38,04 dengan standard deviasi 3,02, sedangkan pada kelompok perlakuan mempunyai rata-rata 53,48 dan standard deviasi 2,21. Pada courage, di kelompok kontrol mempunyai rata-rata 17,78 dengan standard deviasi 1,05, sedangkan pada kelompok perlakuan mempunyai rata-rata 25,26 dan standard deviasi 0,71. Deskripsi nilai patience di kelompok kontrol mempunyai rata-rata 10,48 dengan standard deviasi 0,80, sedangkan pada kelompok perlakuan mempunyai rata-rata 14,22 dan standard deviasi 0,70. Berdasarkan nilai rata-rata pada kedua kelompok tampak rata-rata skor posttest adalah berbeda dan nilai standard deviasi yang hampir sama.

Pengujian hipotesis H1 - H4 dalam penelitian ini membuktikan pengaruh BMT terhadap caring guru yang meliputi knowing, courage dan patience dihitung menggunakan program SPSS versi 20.0 for windows. Pengamatan terhadap caring guru terdiri atas empat bagian yaitu (1) pre test kontrol, (2) pre test perlakuan, (3) post test kontrol dan (4) post test perlakuan. Perbedaan rata-rata keempat hasil pengamatan caring guru menggunakan ANOVA. Hipotesis statistik pada analisis ini adalah :

$\mathrm{H} 0: \mu 1=\mu 2=\mu 3=\mu 4$

$\mathrm{H} 1$ : minimal ada dua m yang berbeda

Tabel 3 Hasil ANOVA dan LSD untuk Knowing

\begin{tabular}{lcccc}
\hline \multirow{2}{*}{ Grup } & Rata- & \multicolumn{3}{c}{ Nilai selisih (n-value) } \\
\cline { 3 - 5 } & rata & $(1)$ & $(2)$ & $(3)$ \\
\hline 1.Pretest Kontrol & 37.00 & - & - & - \\
2.Pretest Perlakuan & 36.67 & $0.33(0.569)$ & - & - \\
3.Posttest Kontrol & 38.04 & $1.04(0.078)$ & $1.37(0.021)$ & - \\
4.Posttest & & & & \\
Perlakuan & 53.48 & $16.48(0.000)$ & $16.81(0.000)$ & $15.44(0.000)$ \\
\hline
\end{tabular}

Bila hasil uji memutuskan untuk menolak H0, maka karaktersitik perbedaan ratarata keempat kelompok akan dilakukan post hoc dengan uji least significant difference (LSD). Berikut ini adalah hasil ANOVA dan uji LSD untuk caring guru yang meliputi knowing, courage dan patience.
$\mathrm{F}=389.902 ; \mathrm{p}$-value $=0,000$

Hasil ANOVA caring guru pada bagian knowing dengan $\mathrm{F}$ sebesar 389,902 $(\mathrm{p}<0,05)$ memberikan kesimpulan bahwa ada perbedaan rata-rata yang signifikan dari keempat kelompok. Karakteristik perbedaan dari perbandingan nilai rata- 
rata didasarkan pada hasil uji LSD. Pada pengamatan pre test, selisih nilai rata-rata knowing antara kelompok kontrol dengan perlakuan sebesar 0,33 berbeda tidak signifikan $(\mathrm{p}>0,05)$. Akan tetapi pada pengamatan post test, selisih nilai rata-rata knowing antara kelompok kontrol dengan perlakuan sebesar 15,44 adalah berbeda

Tabel 4 Hasil ANOVA dan LSD untuk Courage

\begin{tabular}{lcccc}
\hline \multirow{2}{*}{\multicolumn{1}{c}{ Grup }} & \begin{tabular}{c} 
Rata- \\
\cline { 3 - 5 }
\end{tabular} & rata & $(1)$ & Nilai selisih (n-value) \\
\hline 1.Pretest Kontrol & 17.93 & - & - & (2) \\
2.Pretest Perlakuan & 17.89 & $0.04(0.880)$ & - & - \\
3.Posttest Kontrol & 17.78 & $0.15(0.547)$ & $0.11(0.651)$ & - \\
4.Posttest & & & & \\
Perlakuan & 25.26 & $7.33(0.000)$ & $7.37(0.000)$ & $7.48(0.000)$ \\
\hline
\end{tabular}

signifikan $(\mathrm{p}<0,05)$. Perubahan knowing kelompok kontrol dengan menghitung nilai selisih pre test terhadap post test sebesar 1,04 adalah tidak signifikan ( $\mathrm{p}>0,05)$. Sedangkan perubahan knowing yang dihitung dari nilai selisih pre test terhadap post test di kelompok perlakuan sebesar 16,81 adalah signifikan $(\mathrm{p}<0,05)$.

$\mathrm{F}=455.152 ; \mathrm{p}$-value $=0,000$

Hasil ANOVA caring guru pada bagian courage dengan $\mathrm{F}$ sebesar 455,152 $(\mathrm{p}<0,05)$ memberikan kesimpulan bahwa ada perbedaan rata-rata yang signifikan dari keempat kelompok. Karakteristik perbedaan dari perbandingan nilai ratarata didasarkan pada hasil uji LSD. Pada pengamatan pre test, selisih nilai rata-rata courage antara kelompok kontrol dengan perlakuan sebesar 0,04 berbeda tidak signifikan ( $\mathrm{p}>0,05)$. Akan tetapi pada pengamatan post test, selisih nilai rata-rata courage antara kelompok kontrol dengan perlakuan sebesar 7,48 adalah berbeda signifikan $(\mathrm{p}<0,05)$. Perubahan courage

Tabel 5 Hasil ANOVA dan LSD untuk Patience

\begin{tabular}{lcccc}
\hline \multirow{2}{*}{ Grup } & Rata- & \multicolumn{3}{c}{ Nilai selisih (n-value) } \\
\cline { 3 - 5 } & rata & $(1)$ & $(2)$ & $(3)$ \\
\hline 1.Pretest Kontrol & 10.26 & - & - & - \\
2.Pretest Perlakuan & 10.22 & $0.04(0.855)$ & - & - \\
3.Posttest Kontrol & 10.48 & $0.22(0.274)$ & $0.26(0.202)$ & - \\
4.Posttest & & & & \\
Perlakuan & 14.22 & $3.96(0.000)$ & $4.00(0.000)$ & $3.74(0.000)$ \\
\hline
\end{tabular}

kelompok kontrol dengan menghitung nilai selisih pre test terhadap post test sebesar 0,15 adalah tidak signifikan ( $\mathrm{p}>0,05)$. Sedangkan perubahan courage yang dihitung dari nilai selisih pre test terhadap post test di kelompok perlakuan sebesar 7,37 adalah signifikan $(\mathrm{p}<0,05)$.

$\mathrm{F}=187.236 ; \mathrm{p}$-value $=0,000$

Hasil ANOVA caring guru pada bagian patience dengan $\mathrm{F}$ sebesar 187,236 $(\mathrm{p}<0,05)$ memberikan kesimpulan bahwa ada perbedaan rata-rata yang signifikan dari keempat kelompok. Karakteristik perbedaan dari perbandingan nilai ratarata didasarkan pada hasil uji LSD. Pada pengamatan pre test, selisih nilai rata-rata patience antara kelompok kontrol dengan perlakuan sebesar 0,04 berbeda tidak signifikan $(\mathrm{p}>0,05)$. Akan tetapi pada pengamatan post test, selisih nilai rata-rata patience antara kelompok kontrol dengan perlakuan sebesar 3,74 adalah berbeda 
signifikan $(\mathrm{p}<0,05)$. Perubahan patience kelompok kontrol dengan menghitung nilai selisih pre test terhadap post test sebesar 0,22 adalah tidak signifikan $(\mathrm{p}>0,05)$. Sedangkan perubahan patience yang dihitung dari nilai selisih pre test terhadap post test di kelompok perlakuan sebesar 4,00 adalah signifikan $(\mathrm{p}<0,05)$.

Pada pembahasan penelitian ini berangkat dari persoalan kompetensi guru SD dalam pembelajaran: Pertama, keprihatinan terhadap perilaku guru pada saat di kelas maupun di luar kelas yang kurang mempedulikan kebutuhan siswa. Kedua, minimnya pemahaman dan keterampilan tentang sikap dan perilaku guru yang sesuai bagi siswa SD. Ketiga, adanya tuntutan agar guru SD tidak hanya mementingkan target kurikulum untuk kepentingan ujian nasional, akan tetapi kebutuhan non akademis juga lebih diperhatikan. Keempat, hasil pengukuran awal terhadap guru SD di kabupaten Sidoarjo menunjukkan bahwa caring guru SD bervariasi dengan kecenderungan rendah, sehingga perlu ditingkatkan.

Pengaruh Behavior Modeling Training terhadap Caring guru SD dapat digunakan untuk mengetahui pengaruh behavior modeling training terhadap sikap caring guru SD. Pengujian hipotesis penelitian menunjukkan hasil sebagai berikut:

a) Ada perbedaan signifikan caring guru yang dilatih dan yang tidak dilatih dengan BMT. Konstribusi perlakuan BMT dalam meningkatkan caring guru adalah sangat kuat, nilai pre test caring guru adalah 64,8 dan di periode post test menjadi 93,0. Caring guru di kelompok dengan pemberian BMT mengalami peningkatan sebesar 28,2.

b) Ada perbedaan signifikan knowing guru yang dilatih dengan yang tidak dilatih dengan BMT. Kontribusi perlakuan BMT dalam meningkatkan knowing adalah sangat kuat, nilai pretest knowing adalah 36,67 dan di periode post test naik menjadi 53,48. Knowing di kelompok dengan pemberian BMT mengalami peningkatan sebesar 16,81.

c) Ada perbedaan courage guru yang dilatih dan tidak dilatih. Kontribusi perlakuan BMT dalam meningkatkan courage sangat kuat, nilai pre test courage adalah 17,89 dan di periode post test menjadi 25,26. Courage di kelompok dengan pemberian BMT mengalami peningkatan sebesar 7,37.

d) Ada perbedaan signifikan antara patience guru yang dilatih dan yang tidak dilatih dengan BMT. Kontribusi perlakuan BMT dalam meningkatkan patience sangat kuat, nilai pre test patience adalah 10,22 dan di periode post test menjadi 14,22. Patience di kelompok dengan pemberian BMT mengalami peningkatan sebesar 4,00.

Hasil penelitian ini mendukung teoriteori sebelumnya, bahwa pelatihan ini dapat diterapkan untuk meningkatkan caring guru SD, hal ini juga sesuai pendapat Byham \& Pescuric (1996: 72) bahwa pelatihan BMT dapat meningkatkan kinerja yang spesifik dalam hal ini caring guru SD. BMT merupakan teknik pelatihan yang sangat dikenal dan secara luas digunakan dalam pelatihan untuk meningkatkan keterampilan interpersonal dan interaktif.

Keberhasilan penerapan model pelatihan juga ditentukan oleh pemilihan model pelatihan yang disesuaikan dengan karakteristik dan kondisi peserta. Sebagaimana dikemukakan Miller (2009: 28 ), bahwa modeling merupakan cara yang efektif untuk mengajarkan caring. Dalam penelitian ini dijelaskan bahwa instruktur perawat sering menunjukkan 
bagaimana cara mendemonstrasikan perilaku caring dengan cara mempraktekkan perilaku caring melalui diri mereka sendiri. Modeling menjadi salah satu cara yang terbanyak digunakan dalam pendidikan perilaku yang berfokus pada pengajaran caring. Sintak pelatihan mudah dilaksanakan, dan sesuai dengan prinsip pelatihan bagi orang dewasa.

Behavior modeling training melalui sintak modeling, retention process, behavior rehearsal, feedback dan transfer of training, merupakan proses eksplorasi dan penguatan terhadap behavior guru. Penerapan model ini sesuai pendapat Robinson (1982: 59) bahwa BMT telah terbukti efektif dalam merubah perilaku kerja. American Psycological association juga melaporkan bahwa BMT sebagai training methodology yang mampu merubah perilaku di tempat kerja. Paul et. al (1983:41) juga menyatakan bahwa BMT sebagai metode pelatihan yang paling efektif untuk keterampilan mengajar, karena metode ini membolehkan pebelajar untuk meniru perilaku orang lain yang memiliki keterampilan dan ada pengawasan pada saat ia memperaktekkannya. Dengan demikian, penelitian yang dilakukan mendukung teori-teori sebelumnya. Penerapan BMT terbukti efektif untuk meningkatkan caring guru SD.

Sedangkan menurut Teven (2001:28), caring merupakan butir personal yang mendasar bagi guru yang memainkan peranan vital bagi persepsi siswa dalam pembelajaran, sikap, kepuasan, dan persepsi kompetensi guru serta kepercayaan siswa terhadap guru. Penelitian yang telah dilakukan oleh Wentzel (dalam Linley 2006: 36) menunjukkan bahwa tingkat motivasi siswa dipengaruhi oleh kualitas pengajaran dimana kualitas tersebut sangat berhubungan erat bahkan tidak mungkin dipisahkan dengan tindakantindakan guru yang menunjukkan pentingnya caring guru.

\section{SIMPULAN}

Berdasarkan uraian pelaksanaan BMT, hasil analisis serta pembahasan hasil penelitian dapat dijelaskan bahwa BMT dapat dikatakan memiliki pengaruh dalam meningkatkan caring guru SD. Di dalamnya terkandung sintak yang mudah untuk diterapkan. Kemudahan desain, kejelasan urutan, dan model dengan menggunakan film yang menarik, serta bahan bacaan yang sesuai menjadi alasan mengapa pelatihan ini diminati oleh guru SD. Dalam pelaksanaannya, kekompakan, konsentrasi, dan perhatian yang ditunjukkan di kelas eksperimen merupakan indikator yang jelas bahwa pelatihan dengan BMT ini dapat diterapkan dan diterima dengan baik oleh guru. Adapun saran yang perlu disampaikan terkait dengan hasil penelitian ini adalah sebagai berikut.

1) Guru SD diharapkan mengikuti pendidikan dan pelatihan untuk meningkatkan pemahaman maupun keterampilan caring, dan mempraktekkannya di sekolah.

2) LPTK diharapkan mengembangkan kompetensi kepribadian guru dengan menumbuhkan dan mengasah kemampuan caring calon guru melalui pembelajaran yang dapat diintegrasikan dalam mata kuliah.

3) Dinas Pendidikan dan instansi terkait sebaiknya melakukan monitoring pelatihan agar dapat mengukur keberhasilan pelatihan yang sudah dilakukan. Hal ini sebagai bahan evaluasi hasil pelatihan yang diperoleh guru, sebagaimana yang dilakukan pada pelatihan caring melalui behavior modeling training ini, peserta pelatihan tetap dikawal 
keberhasilannya melalui transfer of training pada saat mereka kembali ke sekolah masing-masing.

\section{DAFTAR PUSTAKA}

Anderson, C.S. 1982. The Search for School Climate: A Review of the Research. Review of Educational Research. 52, 368-420.

Atmodiworo.S. 2000. Manajemen Pendidikan Indonesia Jakarta: PT. Ardadijaya.

Brucea, M.A. \& Stellern, J. 2005. Building Caring Community in Teacher Education, Journal of The Teacher Educator, 41 (1), 34-53.

Byham, W. C., \& Pescuric, A. 1996. Behavior Modeling at the teachable moment. Training, 33, 50-53.

McCroskey, J.C. 1992. An Introduction to Communication in The Classroom. Edina, MN: Burgess International Group.

Miller, S. A. \& Anderson, E. S. 2009. Modeling and measuring Caring Behaviors among Nursing Education Faculty. Journal of Nursing Education, 32.

NKongho, N. 1994. The Caring Ability Inventory. In O.L. Strickland \& C.R. Waltz (Eds.), Measurement of Nursing Outcomes (4). New York: Springer Publishing.

Noddings, N. 1992. The challenge to Care in School. New York: Teachers College Press.

Noddings, N. 1984. Caring a Feminine Approach to Ethics and Moral Education, Barkeley: University of California Press.

Noddings, N., Michael S. K. \& Kenneth A. S. 1999. Justice and Caring, the Search for Common Ground in Education. New York: Teachers College Press.
Noddings, N. 2001. The Caring Teacher. Dalam V. Richardson (Ed.), Handbook of research on teaching (4 ${ }^{\text {th }}$ ed., pp.99-105). Washington, DC: American Educationala Research Association.

Noddings, N. 1993. Educating for Intelligent Belief or Unbelief. New York: Teacher College Press.

Paul, J. T. \& Darlene F. R.E. 2005. Jurnal of Applied Psychology, 90(4), 113-124.

Palmer, P.J. 1998. The Courage to Teach. San Fransisco: Jossey-Bass.

Robinson, J.C. 1982. Developing Managers Through Behavior Modeling. Austin, TX: Learning Concepts.

Rogers, D. L. 1994. Conceptions of Caring in a fourth grade classroom. dalam A. R. Prillaman, D. J. Eaken and D. M.Kendrick (Eds) The apestry of Caring. Norwood,NJ: Ablex Publishing.

Rogers, D. L., \& Webb, J. 1991. The ethic of Caring in teacher education. Journal of Teacher Education, 42(3), 173-181.

Sorcher, M. \& Goldstein, A.P. 1972. Behavior Modeling Approach in Training. Personnel Administration.

Wentzel, K. R. 1997. Student Motivation in Middle School: The Role of Perceived Pedagogical Caring. Journal of Educational Psychology, 89 (3), 411419.

Woolfolk, H. A., \& Weinstein, C. 2006. Student and Teacher perspectives on Classroom Management. New Jersey: Erlbaum. 